\title{
Asuhan Keperawatan Pada An. R Dengan Difteri Laring Dengan Keluhan Utama Ketidakefektifan Pola Nafas
}

\author{
Tika Nuryani ${ }^{1}$ \\ ${ }^{1}$ Poltekkes Kemenkes Semarang \\ J1 Tirto Agung Pedalangan Banyumanik Semarang \\ Korespondensi : Tikahitocae.30@mail.com
}

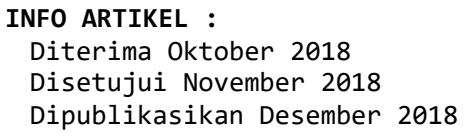

\begin{abstract}
Background: Diphtheria is a serious infectious disease that attacks the upper respiratory tract caused by the bacterium Corynebacterium diphtheria. Objective: To determine the description of nursing care in patients with diphtheria which includes the assessment, intervention, implementation, and evaluation of nursing. Method: This research method is using a case study approach method which is to provide nursing care for diphtheria patients. Results: After nursing care for $3 \times 24$ hours the problem of the ineffectiveness of the breathing pattern has not been resolved while for the problem of nutritional needs less than the body's needs have been resolved. Conclusions : Unresolved nursing problems are the ineffectiveness of breathing patterns. So that requires further treatment.
\end{abstract}

Keywords: Diphtheria, bacteria Corynebacterium diphtheria, infectious diseases

\begin{abstract}
ABSTRAK
Latar Belakang : Difteri merupakan penyakit menular yang serius yang menyerang saluran pernapasan atas yang disebabkan oleh bakteri Corynebacterium diphtheria. Tujuan : Untuk mengetahui gambaran asuhan keperawatan pada pasien dengan difteri yang meliputi pengkajian, intervensi, implementasi dan evaluasi keperawatan. Metode : Metode penelitian ini adalah dengan menggunakan metode pendekatan studi kasus yaitu memberikan asuhan keperawatan pada pasien difteri. Hasil : Setelah dilakukan asuhan keperawatan selama 3 x 24 jam masalah ketidakefektifan pola napas belum teratasi sedangkan untuk masalah kebutuhan nutrisi kurang dari kebutuhan tubuh sudah teratasi teratasi. Kesimpulan : Masalah keperawatan yang belum teratasi adalah ketidakefektifan pola napas. Sehingga membutuhkan perawatan lebih lanjut.
\end{abstract}

Kata Kunci : Difteri, bakteri Corynebacterium diphtheria, penyakit menular 


\section{PENDAHULUAN}

Difteri merupakan penyakit menular yang serius yang menyerang saluran pernapasan atas yang disebabkan oleh bakteri Corynebacterium diphtheria, suatu bakteri Gram positif fakultatif anaerob. Penyakit ini ditandai dengan sakit tenggorokan, demam, malaise dan pada pemeriksaan ditemukan pseudomembran pada tonsil, faring, dan / atau rongga hidung. Difteri adalah penyakit yang ditularkan melalui kontak langsung atau droplet dari penderita. Pemeriksaan khas menunjukkan pseudomembran tampak kotor dan berwarna putih keabuan yang dapat menyebabkan penyumbatan karena peradangan tonsil dan meluas ke struktur yang berdekatan sehingga dapat menyebabkan bull neck. Membran mudah berdarah apabila dilakukan pengangkatan.

Diagnosis cepat harus segera dilakukan berdasarkan gejala klinis, laboratorium (swab tenggorok, kultur, atau PCR) untuk penanganan lebih awal. Tata laksana terdiri dari penggunaan antitoksin spesifik dan eliminasi organisme penyebab.

Komplikasi dari difteri dapat menyebabkan obstruksi jalan napas, miokarditis, paralisis otot palatum, otitis media dan juga dapat menyebar ke paruparu menyebabkan pneumonia. Pencegahan dengan melakukan imunisasi, pengobatan karier, dan penggunaan APD. Penularan disebarkan melalui droplet, kontak langsung dengan sekresi saluran napas penderita atau dari penderita karier. Pada daerah endemis, $3 \%-5 \%$ orang sehat bisa sebagai pembawa kuman difteri toksigenik. Kuman C. diptheriae dapat bertahan hidup dalam debu atau udara luar sampai dengan 6 bulan.

Pada tahun 2014, jumlah kasus difteri 296 kasus dengan jumlah kasus meninggal 16 orang dengan CFR difteri 4\%. Dari 22 provinsi yang melaporkan adanya kasus difteri, provinsi tertinggi terjadi di Provinsi Jawa Timur, yaitu 295 kasus yang berkonstribusi sebesar $74 \%$. Dari total kasus tersebut, $37 \%$ tidak mendapatkan vaksin campak. Sementara pada tahun 2015 terdapat 252 kasus difteri dengan 5 kasus meninggal sehingga CFR 1,98\% dan gambaran menurut umur terbanyak pada usia 5-9 tahun dan 1-4 tahun.

\section{METODE PENELITIAN}

Metode yang digunakan dalam studi kasus ini adalah metode deskriptif dengan pemaparan kasus dan 
menggunakan pendekatan proses keperawatan dengan memfokuskan pada salah satu masalah penting dalam kasus yang dipilih yaitu asuhan keperawatan anak dengan diagnosa difteri laring yang dilakukan pada satu responden.

\section{HASIL}

\section{Pengkajian}

Klien bernama An. R, umur 4 tahun, jenis kelamin laki - laki. Untuk penanggungjawab klien bernama Ny. M, umur 45 tahun, hubungan dengan klien adalah ibu kandung. Setelah dilakukan pengkajian didapatkan data umum sebagai berikut :

1. Keluhan utama

Ibu klien mengatakan anakanya mengeluh sesak napas sejak sehari yang lalu.

2. Riwayat penyakit sekarang

Klien datang ke RS dengan sesak napas yang terjadi sejak sehari yang lalu disertai dengan demam yang tidak terlalu tinggi sudah 2 hari, rewel, dan tidak mau makan.

3. Riwayat penyakit dahulu

An. R pernah dirawat di RS 2 tahun yang lalu dengan demam berdarah. Klien tidak mempunyai penyakit keturunan.
Kemudian setelah dilakukan pemeriksaan fisik pada klien didapatkan hasil :

1. Keadaan umum : Klien terlihat lemah

2. Tingkat kesadaran : Compos mentis

3. Tanda - tanda vital $:$ Nadi $=90$, kali/menit, Suhu $=38,4$ OC, dan RR = $28 \mathrm{kali} / \mathrm{menit}$

4. Kepala : Rambut bersih, kulit kepala bersih

5. Mata : Konjungtiva merah muda, sklera putih, mata sembab

6. Hidung: Lubang hidung kotor, tidak ada polip

7. Mulut : Membran mukosa lembab, mulut kotor, lidah putih, terdapat membran putih pada langit - langit di dekat faring.

8. Leher : Tidak terdapat pembesaran tiroid.

9. Telinga : Bersih

10. Kulit : Turgor kulit kembali dalam 2 detik

11. Paru - paru : Hasil inspeksi dada simetris, palpasi vocal fremitus tidak terkaji, perkusi sonor, auskultasi bunyi vesikuler dan tidak terdapat bunyi otot bantu pernapasan.

12. Jantung :Hasil inspeksi ictus cordis tidak terlihat, palpasi ictus cordis 
teraba, perkusi pekak, auskultasi bunyi S1 dan S2 reguler dan tidak terdapat bunyi tambahan.

13. Abdomen : Hail inspeksi perut datar dan tidak ada benjolan, auskultasi bising usus 12 kali/menit, perkusi timpani, dan dipalpasi tidak ada massa

14. Ekstremitas : Tangan dan kaki bisa digerakkan, tidak terdapat edema pada ekstremitas, tangan kiri terpasang infuse.

Hasil pengkajian pola fungsional :

1. Pola persepsi terhadap kesehatan

: Ibu klien mengatakan setiap anaknya sakit selalu diperiksakan oleh keluarganya

2. Pola aktivitas dan latihan : sebelum sakit aktivitas anak seperti mandi, makan, toileting sebagian di bantu orang tua. Anak aktif dalam bermain dengan temannya. Dan saat sakit aktivitas anak dibantu oleh keluarga dengan skala ketergantungan 2.

3. Pola istirahat dan tidur : sebelum sakit: anak selalu tidur nyenyak malam hari $\pm 9-10$ jam, anak terbiasa tidur siang. Dan saat dirawat di RS anak tidak bisa tidur dan selalu terbangun karena sesak nafas.

4. Pola nutrisi : Ibu klien mengatakan

BB sebelum sakit adalah 17 $\mathrm{kg}$ setelah anak sakit BB klien turun $\mathrm{kg}$ menjadi $15 \mathrm{~kg}$. Turgor kulit kembali dalam 2 detik, mukosa bibir lembab, anak tampak lemas. Diit selama di RS anak mendapatkan nasi, tetapi anak hanya makan 3 potong biscuit.

5. Pola eliminasi : Ibu klien mengatakan sebelum sakit anak BAK 4 - $5 \mathrm{kali} / \mathrm{hari}$, warna kuning jernih kemudian BAB $1 \mathrm{kali} / \mathrm{hari}$ konsistensi lembek dan berwarna kuning kehijauan. Sedangkan saat klien sakit BAK 1 kali/hari dan belum BAB sama sekali.

6. Pola konsep diri: Ibu klien mengatakan sebelum sakit anak ceria dan sering bermain dengan temannya namun saat anak sakit anak rewel.

7. Pola kognitif dan perceptual : tidak ada gangguan dalam pembicararaan, penglihatan, pendengaran dan status mental.

8. Pola peran dan hubungan : anak selalu mendapat dukungan dari keluarga. 9. Pola koping dan toleransi stress : ketika anak kesakitan selalu menangis.

10. Pola seksualitas : anak berjenis kelamin laki - laki.

11. Pola nilai dan kepercayaan : anak beragam islam. 
Setelah dilakukan pengkajian didapatkan pula analisa data sebagai berikut :

Ds : Ibu klien mengatakan anaknya mengeluh sesak napas sejak satu hari yang lalu.

DO : Tampak lemah, RR = 28 kali $/$ menit, $\mathrm{S}=38,4{ }^{\mathrm{O}} \mathrm{C}, \mathrm{N}=90 \mathrm{kali} / \mathrm{menit}$.

Diagnosa Keperawatan

Rumusan prioritas diagnosa untuk An. R adalah ketidakefektifan pola napas.

Intervensi Keperawatan

Rencana keperawatan untuk mengatasi masalah keperawatan ketidakefektifan pola napas pada An. R adalah :

1. Monitor pola napas yang meliputi irama pernapasan, penggunaan otot-otot bantu napas, suara napas, dan frekuensi napas.

2. Auskultasi suara nafas, catat adanya suara nafas tambahan

3. Atur posisi tidur pasien

4. Berikan terapi oksigen

\section{Implementasi Keperawatan}

Tindakan keperawatan yang dilakukan pada An. R selama 3 hari perawatan berturut - turut di rumah sakit yaitu :

\section{Hari ke - 1}

Memonitor pola napas klien yang meliputi irama pernapasan, penggunaan otot-otot bantu napas, suara napas, dan frekuensi napas kemudian mengauskultasi suara paru klien untuk mengetahui ada tidaknya obstruksi jalan napas. Irama napas klien regular, napas cepat dan dalam, tidak ada suara bantu otot pernapasan, $\mathrm{RR}=28 \mathrm{kali} / \mathrm{menit}$, dan tidak ada suara napas tambahan.

Untuk mengurangi sesak napas pada klien, diberikan terapi $\mathrm{O}_{2}$ dengan nassal canul 3 liter/ menit, ibu klien mengatakan anaknya mengeluh sesak napas.

\section{Hari ke - 2}

Dilakukan tindakan keperawatan pengaturan posisi semi fowler pada klien untuk meningkatkan pengisian pada segmen paru sehingga ventilasi maksimal. An. R bersedia dilakukan pengaturan posisi, klien tampak lebih tenang.

Kolaborasi pemberian terapi $\mathrm{O}_{2}$ dengan nassal canul 3 liter/ menit pada klien, ibu klien mengatakan sesak napas pada anaknya sedikit berkurang, $R R=27$ kali/menit. 


\section{Hari ke - 3}

Mempertahankan posisi tidur pasien. Klien terbaring diatas tempat tidur dengan posisi semifowler dan klien tampak nyaman.

Mempertahankan pemberian terapi $\mathrm{O}_{2}$ dengan nassal canul 3 liter/ menit, ibu klien mengatakan anaknya masih mengeluh sesak napas.

\section{Evaluasi Keperawatan}

$\mathrm{S}=$ Ibu klien mengatakan anak masih sesak napas.

$\mathrm{O}=$ Anak masih terpasang $\mathrm{O}_{2}, \mathrm{RR}: 26$ kali/menit, posisi anak semifowler, auskultasi napas tidak terdapat bunyi napas tambahan, anak terlihat tidak rewel

$\mathrm{A}=$ Masalah keperawatan ketidakefektifan pola napas belum teratasi

$\mathrm{P}=$ Lanjutkan intervensi 1,2,3,4

1. Monitor pola napas yang meliputi irama pernapasan, penggunaan otot-otot bantu napas, suara napas, dan frekuensi napas.

2. Auskultasi suara nafas, catat adanya suara nafas tambahan

3. Atur posisi tidur pasien

4. Berikan terapi oksigen

\section{PEMBAHASAN}

Pengkajian

Pembahasan mengenai pengkajian yang dilakukan pada keluarga An. $\mathrm{R}$ didapatkan data bahwa An. R mengeluh sesak nafas sejak satu hari yang lalu. RR $=28 \mathrm{kali} / \mathrm{menit}, \mathrm{S}=38,4{ }^{\circ} \mathrm{C}, \mathrm{N}=90 \mathrm{kali} /$ menit. Menurut Anik Maryunani (2010) Difteri adalah radang tenggorokan yang sangat berbahaya karena menimbulkan tenggorokan tersumbat. Difteri laring biasanya sering disertai dengan gejala sumbatan jalan nafas.

Perumusan Masalah

Berdasarkan data fokus dalam pengkajian maka masalah keperawatan berdasarkan NANDA 2015 - 2017 pada An. R adalah ketidakefektifan pola napas berhubungan dengan gangguan neuromuscular.

Alasan ketidakefektifan pola napas menjadi prioritas diagnosa karena apabila terjadi penyumbatan jalan napas maka otomatis penderita difteri akan mengalami kesulitan dalam bernafas sehingga jika tidak segera ditangani bisa mengakibatkan penderita gagal mendapatkan suplai oksigen yang mengakibatkan kematian pada sel - sel tubuh terutama otak, jantung, paru, serta organ vital. 


\section{Perencanaan Keperawatan}

Untuk mengatasi masalah keperawatan ketidakefektifan pola napas maka disusunlah beberapa rencana keperawatan antara lain monitor pola napas, auskultasi suara nafas, atur posisi tidur pasien, dan kolaborasi pemberian oksigen.

Implementasi Keperawatan

Masalah keperawatan dengan ketidakefektifan pola napas pada An. R belum teratasi namun pasien telah mendapat tindakan terapi yaitu diatur posisi tidurnya untuk memaksimalkan ventilasi dan pemberian oksigen sebanyak 3 liter/menit.

Evaluasi

Telah dilakukan evaluasi pada keluarga klien dan klien dengan hasil :

$\mathrm{S}=\mathrm{Ibu}$ klien mengatakan anak masih sesak napas.

$\mathrm{O}=$ Anak masih terpasang $\mathrm{O}_{2}, \mathrm{RR}: 26$

kali/menit, posisi anak semifowler, auskultasi napas tidak terdapat bunyi napas tambahan, anak terlihat tidak rewel

$\mathrm{A}=$ Masalah keperawatan ketidakefektifan pola napas belum teratasi
$\mathrm{P}=$ Lanjutkan intervensi 1,2,3,4

1. Monitor pola napas yang meliputi irama pernapasan, penggunaan otot-otot bantu napas, suara napas, dan frekuensi napas.

2. Auskultasi suara nafas, catat adanya suara nafas tambahan

3. Atur posisi tidur pasien

4. Berikan terapi oksigen

\section{KESIMPULAN}

Simpulan dari hasil asuhan keperawatan yang telah dilakukan pada An. $\mathrm{R}$ menunjukkan bahwa mampu menjawab tujuan yaitu mendeskripsikan hasil pengkajian, merumuskan diagnosa keperawatan, tindakan keperawatan, melaksanakan tindakan keperawatan, dan mengevaluasi hasil dari tindakan keperawatan.

Hasil dari pengkajian menunjukan An. $\mathrm{R}$ mengeluh sesak nafas.

Masalah keperawatan ada An. R muncul dengan masalah keperawatan ketidakefektifan pola napas berhubungan dengan gangguan neuromuscular.

Rencana asuhan keperawatan pada An. $\mathrm{R}$ difokuskan pada terapi pemberian oksigen dan pengaturan 
posisi, hal ini bertujuan untuk mengurangi keluhan sesak nafas.

Tindakan keperawatan dilakukan sesuai dengan rencana keperawatan, pada An. $\mathrm{R}$ yaitu Memonitor pola napas yang meliputi irama pernapasan, penggunaan otot-otot bantu napas, suara napas, dan frekuensi napas. Mengauskultasi suara nafas, catat adanya suara nafas tambahan. Mengatur posisi tidur pasien, serta memberikan terapi oksigen. Hasil evaluasi menunjukan bahwa An. R masih mengeluh sesak nafas.

\section{UCAPAN TERIMA KASIH}

$$
\text { Untuk terselenggaranya }
$$

penelitian ini kami mengucapkan terima kasih kepada Poltekkes Kemenkes Semarang dan Keluarga yang bersedia menjadi responden dalam penelitian ini.

\section{SARAN}

Berdasarkan asuhan keperawatan yang telah dilakukan pada An. R dan kesimpulan yang telah disusun seperti diatas, maka penulis memberikan saransaran sebagai berikut :

\section{Bagi Perawat}

Sebagai perawat harus memberikan pelayanan yang baik kepada pasien, melakukan semua implementasi sesuai dengan apa yang sudah direncanakan dan berkolaborasi dengan tim medis yang lain.

\section{Bagi Pembaca}

Pembaca disarankan banyak mencari informasi tentang penyakit yang dialami, harus menjaga pola hidup sehat dengan makan makanan sehat sesuai kebutuhan, melakukan olah raga yang teratur, selalu memeriksakan keadaan kesehatan ke pusat pelayanan kesehatan terdekat seperti puskesmas yang teratur untuk mengetahui status kesehatan.

\section{DAFTAR PUSTAKA}

Arifin I, Prasasti C. Faktor Yang Berhubungan Dengan Kasus Difteri Anak Di Puskesmas Bangkalan Tahun

2016. Jurnal Berkalam Epidemologi 2017;26-36.

Bulechek,Gloria.dkk.2013.Nursing

Outcome Classification.Edisi 5: Elsevier.

Hartoyo, E. (2018). Difteri pada Anak. Sari Pediatri, 19(5), 301-306.

Herdman, T.Heather. Nanda International Inc.diagnosis keperawatan : definisi \& klasifikasi 2015-2017. Edisi 10. Jakarta : EGC. 
Morhead, $\quad$ Sue.dkk.2013.Nursing

Interventions Classification.Edisi

6 : Elsevier.

Maryunani, Anik. 2010. Ilmu

Kesehatan Anak Dalam

Kebidanan. Jakarta: CV. Info

Trans Media.

Rahman, F. S., Hargono, A., \& Susilastuti, F. (2016). Penyelidikan Epidemiologi KLB Difteri di Kecamatan Geneng dan Karang Jati Kabupaten Ngawi Tahun 2015. Jurnal Wiyata, 3, 199-213.

Saifudin, N., Wahyuni, C. U., \& Martini, S. (2017). Faktor Risiko Kejadian Difteri Di Kabupaten Blitar Tahun 2015. Jurnal Wiyata Penelitian Sains Dan Kesehatan, 3(1),61-66. 